\title{
Is Eltrombopag Useful in the Treatment of Children with Chronic Immune Thrombocytopenic Purpura
}

\author{
Md. Belayet Hossain ${ }^{1 *}$, Md, Aynal Hoque ${ }^{2}$, Md. Selimuzzaman ${ }^{3}$, Nilufer Akhter Chowdhury Banu ${ }^{4}$, Abdul Wahab ${ }^{5}$
}

\author{
${ }^{1}$ Associate Professor, Department of Paediatric Haematology \& Oncology, Bangladesh Institute of Child Health \& Dhaka Shishu \\ (Children) Hospital, Dhaka, Bangladesh \\ ${ }^{2}$ Associate Professor \& Head, Department of Paediatric Rheumatology, Bangladesh Institute of Child Health \& Dhaka Shishu \\ (Children) Hospital, Dhaka, Bangladesh \\ ${ }^{3}$ Professor \& Head, Department of Paediatric Haematology \& Oncology, Bangladesh Institute of Child Health \& Dhaka Shishu \\ (Children) Hospital, Dhaka, Bangladesh \\ ${ }^{4}$ Registrar, Department of Paediatric Haematology \& Oncology, Bangladesh Institute of Child Health \& Dhaka Shishu (Children) \\ Hospital, Dhaka, Bangladesh \\ ${ }^{5}$ Medical Officer, Department of Paediatric Haematology \& Oncology, Bangladesh Institute of Child Health \& Dhaka Shishu \\ (Children) Hospital, Dhaka, Bangladesh
}

DOI: $10.36347 /$ sjams.2021.v09i04.004

| Received: 05.03.2021 | Accepted: 26.03.2021 | Published: 02.04.2021

*Corresponding author: Md. Belayet Hossain

Abstract

Original Research Article

Background: Chronic immune thrombocytopenic purpura is an autoimmune disease. Platelet count is decreased due to antibody-mediated platelet destruction as well as suppression of platelet production. So enhancement of platelet production could be a targeted goal of treatment. Methods: This is a placebo controlled prospective study conducted in the Department of Pediatric Hematology \& Oncology, Dhaka Shishu (Children) Hospital from July 2018 to June 2020. Eltrombopag was given to chronic immune thrombocytopenic children at the dose of $25-50 \mathrm{mg} / \mathrm{day}$ according to age group and monitored clinically as well as laboratorial parameters including platelet count. Results: In thirteen (65\%) of 20 study children, platelet count began to rise at day 10 and reached peak level at $5^{\text {th }}$ week and all the responded children clinically improved by reduce or disappearance of bleeding manifestations. Eight (40\%) responded patients maintaining platelet count for variable period while taking eltrombopag. The incidences of adverse events like headache, upper respiratory tract infections and raised transaminase (SGPT) are 10\%, 10\% and $15 \%$ respectively. Conclusion: It is revealed that eltrombopag increase platelet count and reduces bleeding manifestations in statistically significant proportion of chronic ITP children. No serious adverse event is seen. So eltrombopag could be use for treatment of children with chronic immune thrombocytopenic purpura.

Keywords: Chronic Immune Thrombocytopenic Purpura, Autoimmune Disease, Platelet Count, Headache.

Copyright $\odot 2021$ The Author(s): This is an open-access article distributed under the terms of the Creative Commons Attribution 4.0 International License (CC BY-NC 4.0) which permits unrestricted use, distribution, and reproduction in any medium for non-commercial use provided the original author and source are credited.

\section{INTRODUCTION}

Immune thrombocytopenic purpura is the most common autoimmune cytopenia in children and defined as isolated low platelet count in the absence of an underlying cause in an otherwise well child [1] due to a variable combination of immune- mediated destruction of platelet by various mechanisms [2, 3] impaired platelet production [4] and inappropriate thrombopoietin response [5]. ITP occurs in 1.9 to 6.4 in 1, 00,000 children [6]. The majority of children with ITP resolve spontaneously within a few weeks and do not require treatment [7], and about $20-30 \%$ children develop chronic ITP when they have persisted thrombocytopenia >12 months [8]. In the chronic form, therapeutic choices are complex and focused on improving health-related quality of life (HRQoL) [9] and controlling bleeding symptoms [10]. A few patients with significant hemorrhage require continuing therapy directed at raising the platelet count. Corticosteroid and intravenous immunoglobulin (IVIG) are recommended as first-line treatment. If first-line therapy failstherapeutic option for managing chronic ITP in children include immunosuppressive therapy (such as rituximab, azathioprine, mycophenolate mofetil and sirolimus) [11, 12], splenectomy and more recently TPO receptor agonists (RAs) [13, 14]. Immunosuppressive agents increase platelet count in ITP primarily by reducing the extent of platelet destruction. But reduced platelet production has led to the use of treatments that enhance thrombopoietins. This approach has focused on TPO, the growth factor underlying megakayopoiesis. TPO is 
the ligand for the TPO receptor on megakaryocytes \& platelets [15-18]. The oral TPO-RA elthrombopag was approved by the US Food \& Drug Administration (FDA) for the use in adult with chronic ITP in 2008 and in pediatric patients $>1$ year of age with chronic ITP who had insufficient response to immunoglobulin, corticosteroid or splenectomy, in August 2015 [19, 20].

\section{Methods \& Materials}

This placebo-controlled prospective study was conducted in the Department of Pediatric Hematology \& Oncology, Dhaka Shishu (Children) Hospital from July 2018 to June 2020 . The number of study case was 20 and control case was o6 children with chronic ITP. Control cases were not agreed to take eltrombopag due to financial constraint.

Inclusion criteria: Age-1-18 years, thrombocytopenia $>12$ months, received at least one previous treatment for ITP with no response and platelet count $<30 \times 10^{9} / \mathrm{L}$ at enrollment. Eltrombopag was orally administered at the dose of $25 \mathrm{mg} /$ day in children aged $>1-5$ years and $50 \mathrm{mg} /$ day in children $6-18$ years old 2 hours before or 2 hours after meal for better absorption, continued up to 24 weeks. The control cases were given Vitamin B complex as placebo. Rescue therapy given if needed. All the children were monitored clinically and by doing platelet count, SGPT, $\&$ S. Creatinine every month.

The primary outcome was the proportion of patients achieving a platelet count of $50 \times 10^{9} / \mathrm{L}$ or more at least once from within 1-24 weeks in the absence of rescue therapy. We assessed safety in all patients receiving eltrombopag throughout the study period. Data were analyzed by SPSS and considered significant at $\mathrm{p}$ value $<0.0001$

\section{Results}

From July, 2018 we began to enroll Chronic ITP children according to inclusion criteria and up to December, 2019 total 20 patients were enrolled as study case and 6 as control case. Among the study 20 children 6 were $>1-5$ years, 14 were 6-18 years old, 7 were girl and 13 were boy (Table-1).

Table-1: Age and sex distribution of study \& control cases

\begin{tabular}{|l|l|l|}
\hline Variables & Study cases & Control cases \\
\hline Age & & \\
\hline$>1-5$ years & $06(30 \%)$ & $02(33 \%)$ \\
\hline $6-18$ years & $14(70 \%)$ & $04(67 \%)$ \\
\hline Sex & & \\
\hline Girl & $07(35 \%)$ & $03(50 \%)$ \\
\hline Boy & $13(65 \%)$ & $03(50 \%)$ \\
\hline
\end{tabular}

In the study group getting Eltrombopag, 13 (65\%) patients began to increase platelet count from day 10 and reached peak level at $5^{\text {th }}$ week and in the placebo group platelet count minimally increased (up to $30 \times 10^{9} /$ L) in $02((33 \%)$ patients (Table-2). Comparison between eltrombopag vs placebo patients was $65 \%$ vs $33 \%$ which is statistically significant (P value $<0.0001)$.

All the $65 \%$ responded patients with increased platelet count showed reduce or disappearance of bleeding manifestations and became hemodynamically stable without concomitant or rescue therapy. Clinically significant bleeding was found in only $2(10 \%)$ non responded study patients vs in $3(50 \%)$ placebo patients which is also statistically significant. These patients required rescue therapy (Table-2). Regarding sustained response, $8(40 \%)$ responded patients in study group were maintaining raised platelet count for variable period which is statistically significant in comparison to placebo patient (Table-2).

Table-2: Distribution of treatment response.

\begin{tabular}{|l|l|l|l|c|}
\hline Variables & Eltrombopag in \% & Placebo in \% & P value & \\
\hline Platelet response & $13(65 \%)$ & $02(33 \%) *$ & $<0.0001$ & Significant \\
\hline Sustained response & $08(40 \%)$ & $00(0 \%)$ & $<0.0001$ & Significant \\
\hline Required rescue therapy & $02(10 \%)$ & $03(50 \%)$ & $<0.0001$ & Significant \\
\hline Clinically significant bleeding & $02(10 \%)$ & $03(50 \%)$ & $<0.0001$ & Significant \\
\hline
\end{tabular}

$*$ The platelet count raised minimally (up to $30 \times 10^{9} / \mathrm{L}$ ).

Platelet count began to rise in eltrombopag group at $10^{\text {th }}$ day and continue to rise at $35^{\text {th }}$ day. Mean platelet count of study and control cases are summarized in Table- 3 . The highest count was $210 \times 10^{9}$ / L.

Table-3: Mean platelet count $\left(\times 10^{9} / \mathrm{L}\right)$ at treatment

\begin{tabular}{|l|l|l|l|l|l|}
\hline Treatment & Day 0 & Day 10 & Day 15 & Day 25 & Day 35 \\
\hline Eltrombopag & 12 & 25 & 50 & 105 & 160 \\
\hline Placebos & 15 & 15 & 20 & 30 & 20 \\
\hline
\end{tabular}

Regarding adverse events with eltrombopag 2 $(10 \%)$ patients developed headache vs $3(50 \%)$ patients in placebo group, $2(10 \%)$ with eltrombopag vs $1(17 \%)$ with placebo developed upper respiratory tract infection 
Belayet Hossain et al; Sch J App Med Sci, Apr, 2021; 9(4): 517-520

and $3(15 \%)$ with eltrombopag vs no patient with placebo having raised SGPT (Table-4). The patients with transaminitis required discontinuation of drug temporarily.

Table-4: Adverse events in Eltrombopag and Placebo group

\begin{tabular}{|l|l|l|}
\hline Adverse events & Eltrombopag group & Placebo group \\
\hline Headache & $2(10 \%)$ & $3(50 \%)$ \\
\hline Upper respiratory tract inflection & $2(10 \%)$ & $1(17 \%)$ \\
\hline Raised SGPT & $3(15 \%)$ & $0(0 \%)$ \\
\hline
\end{tabular}

\section{DISCUSSION}

The age of study children was divided in two categories: >1-5 years and 6-18 years for dosing concern of eltrombopag- 25 vs $50 \mathrm{mg} /$ day which have been followed by other studies [19-23]. Regarding primary outcome, platelet count raised to $50 \times 10^{9} / \mathrm{L}$ or more in $13(65 \%)$ of study cases vs slightly increased in $2(33 \%)$ placebo cases which was statistically significant and close to the other studies [21, 23] but lowers than few studies $[22,24]$. In our study platelet count began to rise at day 10 and reached peak level at day 35 with highest $210 \times 10^{9} / \mathrm{L}$ and similar to the other studies [21, 22]. Regarding clinical improvement, all the $65 \%$ responded patients with increased platelet count showed reduce or disappearance of bleeding manifestations and became hemodynamically stable without concomitant or rescue therapy which are the finding of other studies also [21-23]. Clinically significant bleedings were found in only $14 \%$ nonresponded study patients vs in $50 \%$ placebo patients which is also statistically significant, these patients required rescue therapy. These findings are also similar to few other studies [21, 22]. The sustainability of raised platelet count was maintaining in various levels in $40 \%$ responded children for variable period. These findings are similar or close to the few other studies [21-23]. There was no clinically significant adverse event in our study. Only $2(10 \%)$ patients developed headache, $2(10 \%)$ developed upper respiratory tract infection and $3(15 \%)$ having raised SGPT which are a little beat higher than study abroad [21-25].

\section{CONCLUSiON}

Eltrombopag, a recent FDA approved, oral TPO-RA for pediatric chronic ITP with insufficient response to first-line therapy appeared effective and well-tolerated but further studies are needed to evaluate new doses strategies and real long- term efficacy as well as toxicity of Eltrombopag.

\section{REFERENCES}

1. Kim TO, Despotovic J, Lambert MP. Eltrombopag for use in children with immune thrombocytopenia. Blood advances. 2018 Feb 27;2(4):454-61.

2. McMillan R, Luiken GA, Levy R, Yelenosky R, Longmine RL. Antibody against megakaryocytes in idiopathic thrombocytopenic purpura. JAMA. 1978; 239: 2460-2462.

3. Cines DB, Cuker A, Sempel J W. Pathogenesis of immune thrombocytopenia. Presse Med. 2014; 43: e49-e59.

4. Ballem PJ, Segal GM, Straton JR, Gernsheimer T, Adamson JW, Slichter SJ. Mechanisms of thrombocytopenia in chronic autoimmune thrombocytopenic purpura. Evidence of both impaired platelet production and increased platelet clearance. J Clin Invest. 1987; 80:33-40.

5. Makar RS, Zhukov OS, Sahud MA, Kuter DJ. Thrombopoietin levels in patients with disorders of platelet production. Am J Hematol. 2013; 88:1041-1044.

6. Terrell DR, Beebe LA, Vesely SK, Neas BR, Segal JB, George JN. The incidence of immune thrombocytopenic purpura in children and adults: a critical review of published reports. American journal of hematology. 2010 Mar;85(3):174-80.

7. Neunert CE, Buchanan GR, Imbach P, BoltonMaggs PH, Bennett CM, Neufeld E, Vesely SK, Adix L, Blanchette VS, Kühne T. Bleeding manifestations and management of children with persistent and chronic immune thrombocytopenia: data from the Intercontinental Cooperative ITP Study Group (ICIS). Blood, The Journal of the American Society of Hematology. 2013 May 30;121(22):4457-62.

8. Rodeghiero F, Stasi R, Gernsheimer T, Michel M, Provan D, Arnold DM, Bussel JB, Cines DB, Chong BH, Cooper N, Godeau B. Standardization of terminology, definitions and outcome criteria in immune thrombocytopenic purpura of adults and children: report from an international working group. Blood. 2009 Mar 12;113(11):2386-93.

9. Giordano P, Lassandro G, Giona F, Jankovic M, Nardi M, Nobili B, Notarangelo LD, Russo G, Mackensen SV. ITP-QoL questionnaire for children with immune thrombocytopenia: Italian version validation's. Pediatric hematology and oncology. 2014 Sep 1;31(6):534-47.

10. Provan D, Stasi R, Newland AC, Blanchette VS, Bolton-Maggs P, Bussel JB, Chong BH, Cines DB, Gernsheimer TB, Godeau B, Grainger J. International consensus report on the investigation and management of primary immune thrombocytopenia. Blood. 2010 Jan 14;115(2):168-86. 
Belayet Hossain et al; Sch J App Med Sci, Apr, 2021; 9(4): 517-520

11. De Mattia D, Del Vecchio GC, Russo G, De Santis A, Ramenghi U, Notarangelo L, Jankovic M, Molinari AC, Zecca M, Nobili B, Giordano P. Management of chronic childhood immune thrombocytopenic purpura: AIEOP consensus guidelines. Acta haematologica. 2010;123(2):96109.

12. Grace RF, Shimano KA, Bhat R, Neunert C, Bussel JB, Klaassen RJ, Lambert MP, Rothman JA, Breakey VR, Hege K, Bennett CM. Secondline treatments in children with immune thrombocytopenia: effect on platelet count and patient- centered outcomes. American journal of hematology. $2019 \mathrm{Jul}$;94(7):741-50.

13. Zhang I, Liang Y, Ai Y, Xie J, Li Y, Zheng W. Thrombopoietin-recceptor agonists for children with immune thrombocytopenia: A systematic review> Expert Opin. Pharmacother. 2017; 18:543-51.

14. Massaro J, Chen Y, Ke Z. Efficacy and safety of thrombopoietin receptor agonists in children with chronic immune thrombocytopenic purpura: metaanalysis. Platelets. 2019; 27:1-8.

15. Vainchenker W, Devili N, Methia N, Mouthon MA, Wendling F. Hematopoiesis and its regulation: comparison between erythropoiesis and megakaryocytopenias. Bull Acad Natl Med. 1994; 178: 753-778.

16. Kuter DJ, Begly CG, Recombinant human thrombopoietin: Basic biology and evaluation of clinical studies. Blood. 2002; 100:3457-3469.

17. Von dem Borne A, Folman C, van den Oudenrijn S, Linthorst $G$, de Jong $S$, de Haas $M$. The potential role of thrombopoietin in idiopathic thrombocytopenic purpura. Blood Rev. 2002; 16:57-59.

18. Geddis AE, Linden HM, Kaushansky K. Thrombopoietin: a pan hematopoietic cytokine. Cytokine Growth Factor Rev. 2002; 13:61-73.

19. Burness CB, Keating GB, Garnock-Jones KP. Eltrombopag: A review in Paediatric chronic immune thrombocytopenia. Drugs. 01 May 2016; 76:869-878.

20. European Medicines Agency. Revolade TM (Eltrombopag): EU summary of product characteristics. 2016. http:/www.ema.europa.eu. Accessed Accessed 26 Mar 2021.

21. Bussel JB, de Miguel PG, Despotovic JM, Grainger JD, Sevilla J, Blanchette VS, Krishnamurti L, Connor P, David M, Boayue KB, Matthews DC. Eltrombopag for the treatment of children with persistent and chronic immune thrombocytopenia (PETIT): a randomised, multicentre, placebo-controlled study. The Lancet Haematology. 2015 Aug 1;2(8):e315-25.

22. Grainger JD, Locatelli F, Chotsampancharoen T, Donyush E, Pongtanakul B, Komvilaisak P, Sosothikul D, Drelichman G, Sirachainan N, Holzhauer S, Lebedev V. Eltrombopag for children with chronic immune thrombocytopenia (PETIT2): a randomised, multicentre, placebocontrolled trial. The Lancet. 2015 Oct 24;386(10004):1649-58.

23. Giordano P, Lassandro G, Barone A, Cesaro S, Fotzi I, Giona F, Ladogana S, Miano M, Marzollo A, Nardi M, Notarangelo LD. Use of eltrombopag in children with chronic immune thrombocytopenia (ITP): a real life retrospective multicenter experience of the Italian Association of Pediatric Hematology and Oncology (AIEOP). Frontiers in medicine. 2020 Feb 28;7:66.

24. Ramaswamy K, Hsieh L, Leven E, Thompson MV, Nugent D, Bussel JB. Thrombopoietc agents for the treatment of persistent and chronic immune thrombocytopenia in children. J Pediatr. 2014:165: $600 \mathrm{e}-605 \mathrm{e}$.

25. Burness CB, Keating JGM, Garnock-Jones KP. Eltrombopag: A review in Paediatric Chronic Immune Thrombocytopenia. Drugs. 2016;76(8):869-878. 